\title{
The Influence of Body Mass Index on Luteinizing Hormone Levels after Gonadotropin-Releasing Hormone Stimulation in Girls with Precocious and Advanced Puberty
}

\author{
Seong Yong Lee, M.D. \\ Department of Pediatrics, \\ SMG-SNU Boramae Medical Center, \\ Seoul, Korea
}

\begin{abstract}
Purpose: The aim of this study was to investigate the influence of body mass index (BMI) on the level of peak luteinizing hormone $(\mathrm{LH})$ after gonadotropin-releasing hormone $(\mathrm{GnRH})$ stimulation in girls with central precocious puberty (CPP) and advanced puberty (AP).

Methods: This study conducted a retrospective review of the medical records of 113 girls (7 to 9 years old; 24 CPP, 89 AP) who underwent a GnRH stimulation test. The following parameters were evaluated: chronologic age (CA), bone age (BA), the difference between $B A$ and $C A$ (BA-CA), height, weight, BMI, and the levels of basal $L H$, peak LH, basal follicle stimulating hormone (FSH), peak FSH, and basal estradiol.

Results: The peak LH level was negatively correlated with weight-standard deviation score (SDS) and BMI-SDS; furthermore, the peak LH level was positively correlated with both basal and peak FSH levels. Using multivariate analysis, BMI-SDS was found to be a significant factor in predicting peak LH levels after GnRH administration. When the subjects were divided into four groups by quartile of peak LH level, the mean BMI-SDS of the highest LH group was significantly lower than the mean BMI-SDS of the lowest LH group.

Conclusion: LH levels rise after GnRH administration is blunted in precocious and advanced pubertal girls with high BMI. The impact of BMI on the GnRH stimulation test should be considered when evaluating sexual precocity in girls.
\end{abstract}

Key Words: Body mass index; Luteinizing hormone; Puberty, precocious

\section{Introduction}

사춘기에는 시상하부의 성선자극호르몬 분비호르몬(gonadotropin-releasing hormone, $\mathrm{GnRH}$ )의 분비억제 기전이 해제되면서 $\mathrm{GnRH}$ 의 파동성 분비와 이에 따른 뇌하수체 전엽의 황체화호르몬(luteinizing hormone, LH)과 난포자극호르몬(follicle stimulating hormone, $\mathrm{FSH}$ )의 파동성분비에 의해 성호르몬이 증가되어 2 차 성징이 나타난다. 사춘기 시작시기는 유전적인 경향을 보이고 영양상태, 여러 가지 호르몬, 환경적인 요인에 의해 영향을 받는 것 으로 보인다 ${ }^{1)}$.

일반적으로 성조숙증은 8세 미만의 여아에서 유방발육과 9 세 미만의 남아에서 고환용적이 $4 \mathrm{~mL}$ 이상 되는 경우로 정의하고 있고 여아에서 8세 이상 9 세 미만, 남아에서 9 세 이상 10 세
Address for correspondence:

Seong Yong Lee, M.D.

Department of Pediatrics,

SMG-SNU Boramae Medical Center,

41 Boramae-gil, Dongjak-gu, Seoul

156-707, Korea

Tel: +82.2-870-2363

Fax: +82.2-870-3633

E-mail: gnoygnoes@hanmail.net
ISSN: 2287-1012(Print)

ISSN: 2287-1292(Online)
This is an Open Access article distributed under the terms of the Creative Commons Attribution Non-Commercial License (http:// creativecommons.org/licenses/by-nc/3.0) which permits unrestricted non-commercial use, distribution, and reproduction in any medium, provided the original work is properly cited. 
미만에 사춘기가 시작되는 경우를 조기사춘기로 정의한다로.

중추성 혹은 진성 성조숙증은 시상하부-뇌하수체-성선 축 의 활성화에 의해 발생한 것으로 정의되며 시상하부-뇌하수 체-성선 축의 활성화 없이 발생한 말초성 혹은 가성 성조숙증 과 구분된다. 기질적 원인을 찾을 수 없는 특발성 중추성 성조 숙증은 남아보다 여아에서 압도적으로 많이 발생한다.

성조숙증은 $\mathrm{GnRH}$ 나 시상하부의 성선자극호르몬 분비호 르몬 유도체(gonadotropin- releasing hormone agonist, $\mathrm{GnRHa}$ ) 투여 후 LH 농도의 증가로 활성화된 시상하부-뇌하 수체-성선 축을 확인함으로써 진단할 수 있다. ${ }^{34}$. 대부분의 임 상연구가들은 $\mathrm{GnRH}$ 투여 후 $\mathrm{LH}$ 최고 농도가 $5 \mathrm{IU} / \mathrm{L}$ 이상이거 나 최고 $\mathrm{LH}$ 농도와 최고 $\mathrm{FSH}$ 농도 비가 1이상인 경우 사춘기 가 시작된 것으로 판단하고 있다).

일반적으로 비만이 사춘기 시작시기에 영향을 주어 비만한 소아에서 사춘기가 일찍 시작된다고 알려져 있다 ${ }^{6-8)}$.

한편 정상 성인과 다낭성 난소증후군 환자들을 대상으로 한 연구에서 비만과 LH 분비 억제가 관련이 있다는 결과를 보였고 9) 사춘기 전후의 소아청소년에서도 비만이 LH 분비에 영향을 미친다는 연구들이 발표되었다 ${ }^{10-12)}$.

본 연구에서는 $\mathrm{GnRH}$ 자극 검사상 $\mathrm{LH}$ 최고 농도가 $5 \mathrm{IU} / \mathrm{L}$ 이상으로 사춘기 반응을 보인 7세 이상 9 세 미만의 여아를 대상 으로 체질량지수와 사춘기 진단의 핵심지표인 LH 최고 농도와 연관성이 있는지를 살펴보고자 하였다.

\section{Materials and Methods}

\section{1. 대상}

본 연구는 2008년 1월부터 2012년 9월까지 사춘기 조숙이 의심되어 보라매병원 소아청소년과에 내원한 여아 중, 사춘기 발달단계(Tanner stage) 2 이상의 유방발달을 보이고 골연령 이 역연령보다 증가되어 있으며 $\mathrm{GnRH}$ 자극 검사상 $\mathrm{LH}$ 최고 농도가 $5 \mathrm{IU} / \mathrm{L}$ 이상인 113 명의 여아를 대상으로 하였다. 진단 시 연령이 8세 미만인 경우 성조숙증으로 분류하였고 8세 이상 9 세 미만인 경우는 조기사춘기로 분류하였다. 113 명의 여아 중 중추성 성조숙증은 24 명, 조기사춘기는 89 명이었다. 뇌 병변 등 기질적 원인의 성조숙증과 난소, 부신, 갑상선 기능의 이상 소견을 보이는 경우는 대상에서 제외하였다. 또 7세 미만의 성 조숙증 여아들은 본 연구에서 제외하였다.

\section{2. 방법}

대상 환아들의 의무기록을 후향적으로 검토하여 진단 시 역 연령, 골연령, 키, 체중, $\mathrm{GnRH}$ 자극 검사 결과를 기록하였다. 키는 Harpenden Stadiometer (Holtain Ltd, Crymych, UK) 로 $0.1 \mathrm{~mm}$ 까지 측정하였다. 골연령은 Greulich-Pyle 방법으
로 구하였다 ${ }^{13)}$. 기저 LH, FSH, 에스트라디올(estradiol) 농도 를 측정한 후 합성 성선자극호르몬 분비호르몬 제제(Relefact, Handok Pharmaceuticals, Seoul, Korea) $100 \mu \mathrm{g}$ 을 정맥 주 사하고 15 분, 30 분, 45 분, 60 분, 90 분 후의 LH와 FSH 농도 를 측정하였다. 체질량지수는 체중 $(\mathrm{kg}) /$ 키 $(\mathrm{m})^{2}$ 의 식으로 계 산하였고 2007년 한국 소아청소년 표준성장도표 ${ }^{14)}$ 을 이용하 여 역연령 및 골연령을 기준으로 한 키, 체중, 체질량지수의 표 준편차점수(standard deviation score, SDS)를 구하였다. $\mathrm{LH}$ 와 FSH 농도는 IRMA 방법(DIAsource ImmunoAssays S.A., Nivelles, Belgium)으로 측정하였다. 에스트라디올 농도는 RIA (Siemens Healthcare Diagnostics Inc. Erlangen, Germany) 방법으로 측정하였다.

\section{3. 통계}

결과는 평균표준편차로 표현하였고 IBM-SPSS (version 20.0, SPSS Inc., Chicago, IL, USA)을 이용하여 자료를 분 석하였다. 성조숙증 군과 조기사춘기 군의 비교는 $t$-test를 이용하였고 LH 최고 농도와 여러 인자들 사이의 상관관계는 Pearson correlation analysis를 이용하였다. 다중회귀분석 방 법으로 LH 최고 농도에 영향을 미치는 인자에 대해 분석하였 다. 또 $\mathrm{LH}$ 최고 농도 값을 사분위수를 기준으로 4 개의 집단으 로 나누고 집단 간의 체질량지수의 평균을 ANOVA 로 분석하였 다. $P<0.05$ 인 경우 통계적으로 의미가 있다고 해석하였다.

\section{Results}

\section{1. 대상 환아의 특성}

본 연구의 대상 환아들의 역연령은 $8.41 \pm 0.43$ 세, 골연령은 $10.21 \pm 0.26$ 세였다. 역연령과 골연령은 모두 성조숙증 군이 조기사춘기 군보다 유의하게 낮았다. 골연령과 역연령의 차이 는 $1.81 \pm 0.66$ 년이었고 성조숙증 군이 조기사춘기 군보다 유 의하게 골연령이 앞서 있었다.

전체 대상 여아들의 평균키는 $131.94 \pm 4.27 \mathrm{~cm}$ 였고 성조숙 증 군과 조기사춘기 군 사이에 유의한 차이는 없었다. 역연령을 기준으로 한 키 표준편차점수(height-SDS, Ht-SDS)는 0.78 \pm 76 이었고 성조숙증 군에서 조기사춘기 군보다 의미 있게 높 았으나, 골연령을 기준으로 한 $\mathrm{Ht}-\mathrm{SDS}$ 는 전체 $-0.94 \pm 0.65$ 였고, 성조숙증 군과 조기사춘기 군 간에 차이를 보이지 않았 다.

체중은 $30.95 \pm 4.40 \mathrm{~kg}$ 이었고 성조숙증 군과 조기사춘기 군 간에 차이를 보이지 않았다. 역연령을 기준으로 한 체중 표준편 차점수(weight-SDS, Wt-SDS)는 0.69土0.74였고 성조숙증 군에서 조기사춘기 군보다 의미 있게 높았으나 골연령을 기준 
으로 한 Wt-SDS는 $-0.47 \pm 0.73$ 이었고 두 군 간에는 차이를 보이지 않았다.

체질량지수는 $17.73 \pm 1.93$, 역연령 기준의 체질량지수 표준 편차점수(body mass index-SDS, BMI-SDS)는 0.46 \pm 0.82 , 골연령을 기준으로 한 $\mathrm{BMI}-\mathrm{SDS}$ 는 $0.01 \pm 0.78$ 이었다. 체질량 지수, 역연령 기준의 BMI-SDS, 골연령 기준의 BMI-SDS는 성조숙증 군과 조기사춘기 군 간에 차이가 없었다.

$\mathrm{LH}$ 기저 농도 및 최고 농도는 각각 $0.87 \pm 0.61 \mathrm{IU} / \mathrm{L}, 12.64$ $\pm 8.86 \mathrm{IU} / \mathrm{L}$ 였고 성조숙증 군과 조기사춘기 군 간에 차이가 없 었다. FSH 기저 농도 및 최고 농도는 $2.42 \pm 1.41 \mathrm{IU} / \mathrm{L}, 13.01$ \pm 5.82 였고 기저 에스트라디올 농도는 $9.46 \pm 6.43 \mathrm{pg} / \mathrm{mL}$ 이
었으며 성조숙증 군과 조기사춘기 군 간에 차이가 없었다(Table 1).

\section{2. ㄴH 최고 농도와 체질량지수와의 관계}

$\mathrm{GnRH}$ 자극 검사 시 $\mathrm{LH}$ 최고 농도와 여러 인자들의 상관 관계를 살펴보았을 때 역연령 및 골연령 기준의 BMI-SDS 와 Wt-SDS가 LH 최고 농도와 유의한 음의 상관관계를 보였 다 (BMI-SDS for CA $r=-0.352, P<0.001$; BMI-SDS for BA, $r=-0.359, P<0.001$; Wt-SDS for CA, $r=-0.330, P<$ 0.001 ; Wt-SDS for BA, $r=-0.352, P<0.001$ ).

Table 1. Clinical characteristics

\begin{tabular}{|c|c|c|c|c|}
\hline & Total $(n=113)$ & $\operatorname{CPP}(n=24)$ & $\operatorname{AP}(n=89)$ & $P$ value* \\
\hline CA (yr) & $8.41 \pm 0.43$ & $7.75 \pm 0.27$ & $8.58 \pm 0.26$ & 0.001 \\
\hline $\mathrm{BA}(\mathrm{yr})$ & $10.21 \pm 0.63$ & $9.97 \pm 0.73$ & $10.28 \pm 0.58$ & 0.032 \\
\hline $\mathrm{BA}-\mathrm{CA}(\mathrm{yr})$ & $1.81 \pm 0.66$ & $2.22 \pm 0.74$ & $1.69 \pm 0.60$ & 0.001 \\
\hline Height $(\mathrm{cm})$ & $131.94 \pm 4.27$ & $130.68 \pm 4.75$ & $132.28 \pm 4.10$ & 0.104 \\
\hline Height-SDS for CA & $0.78 \pm 0.76$ & $1.23 \pm 0.77$ & $0.65 \pm 0.71$ & 0.001 \\
\hline Height-SDS for BA & $-0.94 \pm 0.65$ & $-0.91 \pm 0.73$ & $-0.95 \pm 0.63$ & 0.823 \\
\hline Weight (kg) & $30.95 \pm 4.40$ & $30.34 \pm 4.30$ & $31.12 \pm 4.44$ & 0.447 \\
\hline Weight-SDS for CA & $0.69 \pm 0.74$ & $1.03 \pm 0.64$ & $0.59 \pm 0.74$ & 0.009 \\
\hline Weight-SDS for BA & $-0.47 \pm 0.73$ & $-0.42 \pm 0.68$ & $-0.49 \pm 0.75$ & 0.705 \\
\hline $\mathrm{BMI}\left(\mathrm{kg} / \mathrm{m}^{2}\right)$ & $17.73 \pm 1.93$ & $17.72 \pm 1.94$ & $17.73 \pm 1.94$ & 0.989 \\
\hline BMI-SDS for CA & $0.46 \pm 0.82$ & $0.64 \pm 0.74$ & $0.41 \pm 0.83$ & 0.222 \\
\hline BMI-SDS for BA & $0.01 \pm 0.78$ & $0.07 \pm 0.69$ & $-0.00 \pm 0.80$ & 0.666 \\
\hline LH basal (IU/L) & $0.87 \pm 0.61$ & $0.88 \pm 0.61$ & $0.87 \pm 0.62$ & 0.930 \\
\hline LH peak (IU/L) & $12.64 \pm 8.86$ & $10.93 \pm 6.29$ & $13.10 \pm 9.41$ & 0.295 \\
\hline FSH basal (IU/L) & $2.42 \pm 1.42$ & $2.04 \pm 1.40$ & $2.52 \pm 1.42$ & 0.140 \\
\hline FSH peak (IU/L) & $13.01 \pm 5.82$ & $13.93 \pm 6.06$ & $12.76 \pm 5.76$ & 0.386 \\
\hline Estradiol (pg/mL) & $9.46 \pm 6.43$ & $10.08 \pm 7.44$ & $9.29 \pm 6.16$ & 0.594 \\
\hline
\end{tabular}

Abbreviations: CPP, central precocious puberty; AP, advanced puberty; CA, chronologic age; BA, bone age; SDS, standard deviation score; $\mathrm{BMI}$, body mass index; LH, luteinizing hormone; $\mathrm{FSH}$, follicle stimulating hormone.

* By comparison between CPP group and AP group.

Table 2. Pearson correlation analysis between peak LH level and parameters

\begin{tabular}{|c|c|c|c|c|c|c|}
\hline \multirow{2}{*}{ Parameter } & \multicolumn{2}{|c|}{ Total $(n=113)$} & \multicolumn{2}{|c|}{$\mathrm{CPP}(n=24)$} & \multicolumn{2}{|c|}{$\operatorname{AP}(n=89)$} \\
\hline & $\mathrm{R}$ & $P$ value & $\mathrm{R}$ & $P$-value & $\mathrm{R}$ & $P$ value \\
\hline CA (yr) & 0.163 & 0.085 & 0.122 & 0.570 & 0.142 & 0.184 \\
\hline$B A(y r)$ & 0.134 & 0.157 & 0.164 & 0.443 & 0.110 & 0.303 \\
\hline BA-CA (yr) & 0.021 & 0.825 & 0.119 & 0.579 & 0.045 & 0.672 \\
\hline Height-SDS for CA & -0.138 & 0.146 & -0.008 & 0.972 & -0.134 & 0.210 \\
\hline Height-SDS for BA & -0.176 & 0.063 & -0.089 & 0.678 & -0.196 & 0.065 \\
\hline Weight-SDS for CA & -0.330 & $<0.001$ & -0.303 & 0.151 & -0.320 & 0.002 \\
\hline Weight-SDS for BA & -0.352 & $<0.001$ & -0.406 & 0.049 & -0.344 & 0.001 \\
\hline BMI-SDS for CA & -0.352 & $<0.001$ & -0.420 & 0.041 & -0.334 & 0.001 \\
\hline BMI-SDS for BA & -0.359 & $<0.001$ & -0.468 & 0.021 & -0.343 & 0.001 \\
\hline LH, basal & 0.084 & 0.387 & -0.047 & 0.827 & 0.109 & 0.309 \\
\hline FSH, basal & 0.275 & 0.003 & 0.078 & 0.718 & 0.300 & 0.004 \\
\hline FSH, peak & 0.321 & 0.001 & -0.084 & 0.696 & 0.414 & 0.000 \\
\hline Estradiol, basal & 0.058 & 0.547 & 0.382 & 0.423 & -0.003 & 0.981 \\
\hline
\end{tabular}

Abbreviations: CPP, central precocious puberty; AP, advanced puberty; CA, chronologic age; BA, bone age; SDS, standard deviation score; $\mathrm{BMI}$, body mass index; LH, luteinizing hormone; FSH, follicle stimulating hormone. 
역연령, 골연령, 골연령과 역연령의 차, $\mathrm{Ht}-\mathrm{SDS}$ 등은 $\mathrm{LH}$ 최고 농도와 상관관계를 보이지 않았다. $\mathrm{LH}$ 최고 농도는 기 저 $\mathrm{FSH}$ 농도( $r=0.275, P=0.003)$, 최고 $\mathrm{FSH}$ 농도 $(r=0.321$, $P=0.001)$ 와 양의 상관관계를 보였으나 기저 $\mathrm{LH}$ 농도 및 에스 트라디올 농도와는 유의한 상관관계를 보이지 않았다(Table 2).

역연령, 골연령, 골연령과 역연령 차이, 역연령 기준 BMI$\mathrm{SDS}$, 기저 LH 농도, 기저 FSH 농도, 기저 에스트라디올 농도 등을 독립변수로 하고 최고 LH 농도를 종속변수로 한 단계적 다중회귀분석을 시행하였을 때 BMI-SDS와 기저 FSH 농도, 골연령이 최고 LH 농도에 영향을 미치는 인자들로 의미가 있었 다(Table 3).

본 연구 대상아들을 최고 LH 농도의 사분위수를 기준으로 4 군으로 나누었다. 즉 $\mathrm{LH}$ 최고농도가 $7.0 \mathrm{IU} / \mathrm{L}$ 미만을 1 군 (n=28), 7.0 IU/L 이상 $9.1 \mathrm{IU} / \mathrm{L}$ 미만을 2군(n=28), $9.1 \mathrm{IU} /$ $\mathrm{L}$ 이상 $16.6 \mathrm{IU} / \mathrm{L}$ 미만을 3군(n=28), $16.6 \mathrm{IU} / \mathrm{L}$ 이상을 4군 $(\mathrm{n}=29)$ 으로 하여 각 군 간의 역연령과 골연령 기준 BMI-SDS

Table 3. Stepwise multivariate analysis associated with peak $\mathrm{LH}$ level $\left(r^{2}=0.222\right)$

\begin{tabular}{lccc}
\hline Variable & Estimate & SE & $P$ value \\
\hline BMI-SDS & -3.920 & 0.927 & $<0.001$ \\
FSH, basal & 1.645 & 0.534 & 0.003 \\
BA & 2.405 & 1.213 & 0.05 \\
\hline
\end{tabular}

The covariate entered into the model as potential predictors included CA, BA, BA-CA, height-SDS, weight-SDS, BMI-SDS, basal LH level, basal FSH level, basal estradiol level.

Abbreviations: SE, standard error; BMI, body mass index; SDS, standard deviation score; FSH, follicle stimulating hormone.; BA, bone age; CA, chronologic age; LH, luteinizing hormone; FSH, follicle stimulating hormone.

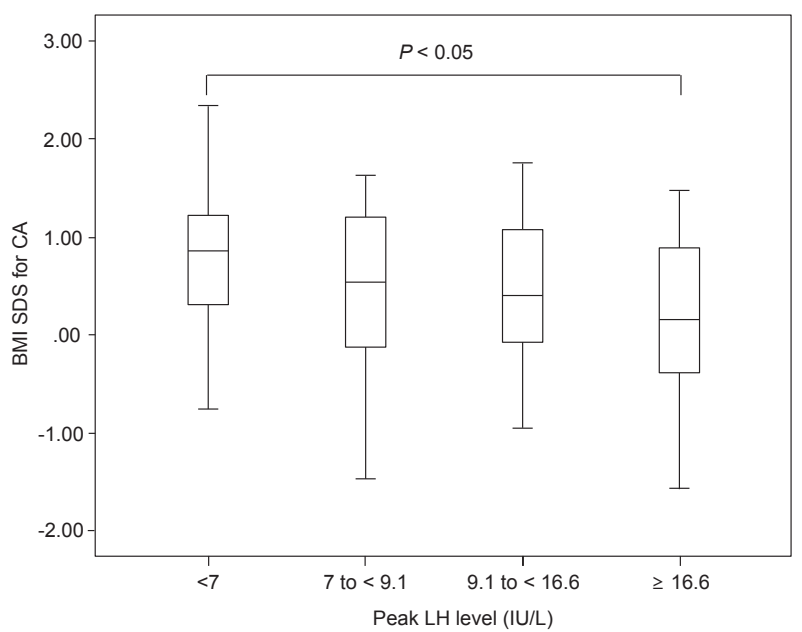

Fig. 1. Body mass index standard deviation score for chronologic age according to peak luteinizing hormone $(\mathrm{LH})$ level quartile: $\mathrm{LH}$, less than $<7 \mathrm{IU} / \mathrm{L}$ (group 1 , $n=28$ ), LH 7 to less than $9.1 \mathrm{IU} / \mathrm{L}$ (group $2, n=28$ ), LH 9.1 to less than $16.6 \mathrm{IU} /$ $\mathrm{L}$ (group $3, n=28$ ), and $L H$ more than $16.6 \mathrm{IU} / \mathrm{L}$ (group $4, n=29$ ). Abbreviations: CA, chronologic age; SDS, standard deviation score; BMI, body mass index; LH, luteinizing hormone.
를 비교하였을 때 유의한 차이를 보였다(BMI-SDS for CA, $P=0.01$; BMI-SDS for BA, $P=0.003$ by ANOVA). 역연령 기 준의 $\mathrm{BMI}-\mathrm{SDS}$ 는 1 군 $0.80 \pm 0.68,2$ 군 $0.54 \pm 0.78,3$ 군 0.42 $\pm 0.73,4$ 군 $0.09 \pm 0.93$ 이었고 골연령 기준의 BMI-SDS 는 1 군 $0.35 \pm 0.62,2$ 군 $0.11 \pm 0.71,3$ 군 $-0.02 \pm 0.74,4$ 군 $-0.38 \pm 0.86$ 로 $\mathrm{LH}$ 최고 농도가 높은 군 일수록 $\mathrm{BMI}-\mathrm{SDS}$ 가 낮아지는 경향을 보였다. 또 $\mathrm{LH}$ 최고 농도가 가장 높은 4군의 역연령 및 골연령 기준 $\mathrm{BMI}-\mathrm{SDS}$ 는 1군에 비해 유의하게 낮았 다(BMI-SDS for CA, $P=0.006$; BMI-SDS for BA, $P=0.002$ ) (Figs. 1 and 2).

\section{Discussion}

본 연구는 성조숙증 및 조기사춘기 여아에서 $\mathrm{GnRH}$ 투여 후 $\mathrm{LH}$ 최고 농도가 체질량지수와 음의 상관관계 있다는 것을 보여 주었다. 이는 비만할수록 사춘기가 빨리 시작된다고 하더라도 체질량지수가 높을수록 사춘기 반응이 억제될 수도 있다는 다 소 역설적인 가능성을 제시하고 있다.

현재 통용되고 있는 여아의 성조숙증 진단 기준연령은 8세이 지만 전 세계적으로 사춘기 시작 연령이 빨라짐에 따라 그 진단 연령을 더 낮추어야 한다는 주장도 있다 ${ }^{7}$. 또한 성조숙증과 조 기사춘기는 하나의 병태생리의 연장선에서 이해하는 것이 더 합리적일 수도 있다. 따라서 본 연구에서는 7세 미만의 비교적 어린 성조숙증 환아들은 제외하고 7세 이상의 성조숙증 환아들 과 8세 이후 9 세 미만에 진단된 조기사춘기 환아들을 대상으로 하였다. 8세 이후에 진단된 경우에도 이차 성징의 발현시기가 8 세 미만이면 임상적으로 성조숙증으로 진단되지만 환아나 보호

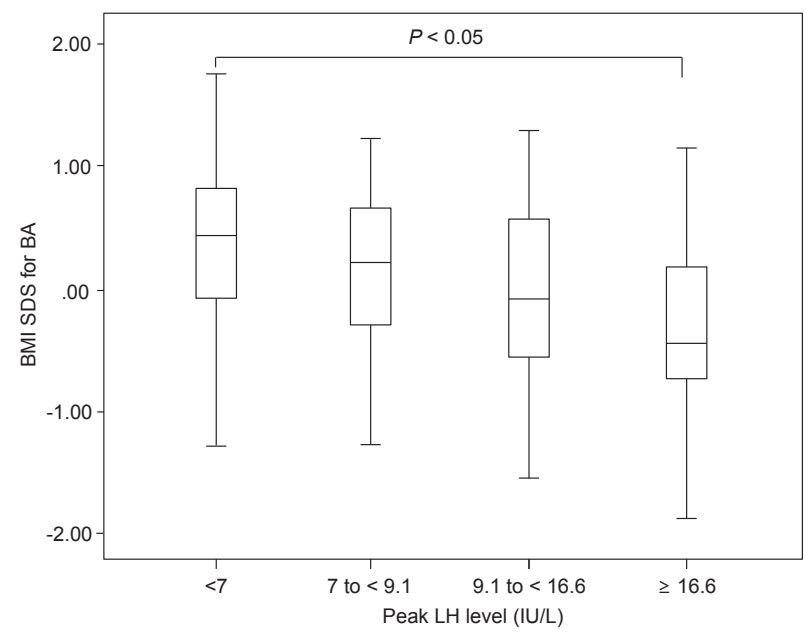

Fig. 2. Body mass index standard deviation score for bone age according to peak luteinizing hormone (LH) level quartile: LH, less than $<7 \mathrm{IU} / \mathrm{L}$ (group $1, n=$ 28), LH 7 to less than $9.1 \mathrm{IU} / \mathrm{L}$ (group 2, $n=28$ ), LH 9.1 to less than $16.6 \mathrm{IU} / \mathrm{L}$ (group $3, n=28$ ), and LH more than 16.6 IU/L (group 4, $n=29$ ). Abbreviations: BA, bone age; SDS, standard deviation score; BMI, body mass index; LH, luteinizing hormone. 
자의 기억이 확실하지 않고 객관적 근거가 불분명한 경우 진단 일 기준으로 8세 이상이면 조기사춘기 군에 포함시켰다.

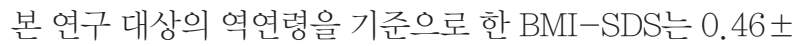
0.82 로 64.4 백분위수에 해당하였고 골연령을 기준으로 한 BMI-SDS는 0.01 0.78로 51.1 백분위수로서, 빠른 사춘기를 주소로 내원하여 성조숙증 혹은 조기사춘기로 진단받은 본 연 구의 대상 여아들은 평균적으로 비만하지 않았다.

본 연구에서 역연령 기준의 체질량지수는 평균 이상이었으 나 골연령 기준의 체질량지수는 평균에 가까운 것으로 보아 본 연구의 대상 여아들은 체질량지수의 증가에 의해 사춘기의 발 현이 앞당겨졌다기 보다는 사춘기가 빨리 시작되어 성장이 빨 라짐으로써 상대적으로 체질량지수가 평균 이상인 것으로 보였 다.

한편 여러 연구들에서 비만할수록 LH 농도가 감소된다는 결 과를 보고하였다. 성인 다낭성 난소증후군을 대상으로 한 연구 들에서 체질량지수가 높을수록 기저 $\mathrm{LH}$ 농도 및 $\mathrm{GnRH}$ 자극에 의한 LH 반응이 감소된다고 하였다 ${ }^{9}{ }^{15)}$. 소아 청소년을 대상으 로 한 연구들에서도 비만한 경우 사춘기 전 ${ }^{16)}$ 사춘기 초기 ${ }^{11)}$ 수 면과 관련된 LH 농도의 증가가 억제됨을 보였다.

Bordini 등 ${ }^{17)}$ 은 비만과 premature adrenarche가 동반된 여 아에서 $\mathrm{GnRHa}$ 투여 후 LH 분비가 억제됨을 보였다. Lee 등 ${ }^{22}$ 은 성조숙증 남아에서 체질량 지수가 높은 경우 $\mathrm{GnRH}$ 자극 검 사상 최고 LH 농도가 감소되었다고 보고하였다.

$\mathrm{BMI}$ 증가가 $\mathrm{GnRH}$ 에 의한 $\mathrm{LH}$ 반응을 억제시키는 기전은 명 확하지 않다. 비만과 동반된 남성호르몬 증가, 고인슐린혈증, 렙틴 저항성과 neuropeptide $\mathrm{Y}(\mathrm{NPY})$ 의 증가 등이 가능한 원 인으로 제시되고 있다. McCartney 등 ${ }^{18)}$ 은 사춘기 초기의 비만 한 여아들은 혈중 테스토스테론 농도가 증가되어 있고 이것이 $\mathrm{LH}$ 혈중 농도 감소와 관련이 있을 것으로 추정하였다. 이는 앞 에서 언급한 비만이 동반된 다낭성 난소증후군 성인에서 LH 농 도 감소를 보이는 기전과 유사할 것이라는 가정에서 유추된 것 이다. 반면 Lee 등 ${ }^{12}$ 의 연구에서 비만한 성조숙증 남아들도 본 연구와 마찬가지로 $\mathrm{GnRH}$ 투여에 의한 $\mathrm{LH}$ 반응을 보였는데, 비만한 남아들은 테스토스테론 농도가 낮은 것으로 알려져 있 어 남성호르몬 증가에 의한 LH 억제기전을 설명하기 위해서는 앞으로 추가적인 연구가 필요할 것으로 보인다.

Lawson 등 ${ }^{19}$ 의 성인 여성을 대상으로 한 연구에서는 $\mathrm{GnRH}$ 자극 검사시 인슐린을 주입하면 정상인에서는 $\mathrm{LH}$ 농도에 영향 을 미치지 못하였으나 다낭성 난소증후군 환자 들은 $\mathrm{GnRH}$ 에 의한 LH 반응이 억제되었다고 하였다. 이는 비만에 동반된 고 인슐린혈증이 $\mathrm{GnRH}$ 자극에 의한 $\mathrm{LH}$ 분비에 영향을 미칠 수 있을 가능성을 시사한다.

한편 Tortoriello 등ㅇ)은 마우스를 대상으로 한 연구를 통하여 비만과 관련된 렙틴의 증가가 중추성 렙틴 저항성을 초래하고 시상하부에서 NPY 발현이 증가되어 $\mathrm{GnRH}$ 발현이 억제된다고
보고하였다.

본 연구와 달리 Lee 등 ${ }^{21)}$ 의 연구에서는 $\mathrm{GnRH}$ 자극 검사상 최고 LH 농도는 BMI-SDS와 상관관계를 보이지 않았는데 본 연구와 차이점은 최고 $\mathrm{LH}$ 농도가 $5 \mathrm{IU} / \mathrm{L}$ 미만인 정상군을 포함 하여 분석을 하였고 성조숙증 환아들의 최저 연령을 제한하지 않아 대상군의 연령범위가 넓었을 가능성이 있다.

반면 모든 연구들에서 일관된 결과를 보이지는 않지만 성조 숙증이 의심되어 시행한 $\mathrm{GnRH}$ 검사상 정상군에서 성조숙증으 로 진단된 군보다 $\mathrm{BMI}-\mathrm{SDS}$ 가 높았다는 몇몇 연구 결과들이 있다 ${ }^{22,23)}$. 이들 연구에서는 증가된 BMI가 LH 농도의 증가를 억제시켜 정상 반응을 나타냈을 가능성도 있어 보인다.

본 연구의 결과 최고 $\mathrm{FSH}$ 농도는 최고 LH 농도와는 양의 상 관관계를 보였으나 체질량지수와는 상관관계를 보이지 않았다. 따라서 사춘기 반응의 양성기준을 최고 LH 농도로 하든지 최고 $\mathrm{LH}, \mathrm{FSH}$ 농도비를 기준으로 하든지 체질량지수가 높을 경우 에는 성조숙증 진단 시 주의를 요한다.

본 연구는 여러 가지 제한점이 있다. 첫째 의무기록 검토를 통한 후향적 연구로서 인과 관계를 명확히 알 수가 없다. 둘째, 8 세 전후 1 년의 여아들을 동일한 질환의 스펙트럼으로 가정하 고 분석을 하였고 8세 이후의 환아가 더 많았다. 실제로 6-7세 미만의 명백한 성조숙증 여아들에서도 동일한 결과가 도출될 지는 알 수 없다. 좀 더 많은 수의 환아를 대상으로 성조숙증의 연령을 세분화하여 분석한다면 7 세 미만의 더 어린 성조숙증 환아에서는 다른 결과가 나올 가능성도 있다. 셋째, 비만과 동 반된 남성호르몬 과다와 인슐린 저항성 등의 평가가 이루어지 지 못했다. 넷째, 체질량지수가 높은 여아에서 $\mathrm{GnRH}$ 검사 시 $\mathrm{LH}$ 최고 농도가 낮다는 본 연구의 결과가 임상적으로 의미하는 바가 비만한 경우 사춘기의 시작이나 진행이 늦다는 것인지 아 니면 실제 사춘기 상태를 저평가하게 하는 것인지 확실하지 않 다. 이러한 제한점에도 불구하고 여아에서 높은 체질량지수는 $\mathrm{GnRH}$ 자극 검사의 $\mathrm{LH}$ 증가를 억제시키는 것으로 보이며 그 기전과 임상적 의미에 대해 더 많은 연구가 이루어져야 할 것으 로 보인다.

\section{References}

1) Parent AS, Teilmann G, Juul A, Skakkebaek NE, Toppari J, Bourguignon JP. The timing of normal puberty and the age limits of sexual precocity: variations around the world, secular trends, and changes after migration. Endocr Rev 2003:24:668-93.

2) Mul D, Hughes IA. The use of GnRH agonists in precocious puberty. Eur J Endocrinol 2008;159 (Suppl 1):3-8.

3) Neely EK, Wilson DM, Lee PA, Stene M, Hintz RL. Spontaneous serum gonadotropin concentrations in the evaluation of precocious puberty. J Pediatr 1995;127:47-52.

4) Bhatia S, Neely EK, Wilson DM. Serum luteinizing hormone rises within minutes after depot leuprolide 
injection: implications for monitoring therapy. Pediatr 2002;109:e30.

5) Carel JC, Leger J. Clinical practice. Precocious puberty. N Engl J Med 2008;358:2366-77.

6) Burt Solorzano CM, McCartney CR. Obesity and the pubertal transition in girls and boys. Reproduction 2010;140:399-410.

7) Kaplowitz PB. Link between body fat and the timing of puberty. Pediatrics 2008;121 Suppl 3:S208-17.

8) Ahmed ML, Ong KK, Dunger DB. Childhood obesity and the timing of puberty. Trends Endocrinol Metab 2009;20:237-42.

9) Taylor AE, McCourt B, Martin KA, Anderson EJ, Adams JM, Schoenfeld D, et al. Determinants of abnormal gonadotropin secretion in clinically defined women with polycystic ovary syndrome. J Clin Endocrinol Metab 1997;82:2248-56.

10) McCartney CR, Prendergast KA, Blank SK, Helm KD, Chhabra S, Marshall JC. Maturation of luteinizing hormone (gonadotropin-releasing hormone) secretion across puberty: evidence for altered regulation in obese peripubertal girls. J Clin Endocrinol Metab 2009;94:56-66.

11) Bordini B, Littlejohn E, Rosenfield RL. Blunted sleeprelated luteinizing hormone rise in healthy premenarcheal pubertal girls with elevated body mass index. J Clin Endocrinol Metab 2009;94:1168-75.

12) Lee HS, Park HK, Ko JH, Kim YJ, Hwang JS. Impact of body mass index on luteinizing hormone secretion in gonadotropin-releasing hormone stimulation tests of boys experiencing precocious puberty. Neuroendocrinology In press 2012.

13) Greulich WW, Pyle SI. Radiologic Atlas of Skeletal Development of the Hand and Wrist. 2nd ed. Standford: Stanford University Press; 1959.

14) Moon JS, Lee SY, Nam CM, Choi JM, Choe BK, Seo JW, et al. 2007 Korean National Growth Charts: review of developmental process and an outlook. Korean J Pediatr 2008;51:1-25.
15) Arroyo A, Laughlin G, Morales A, Yen S. Inappropriate gonadotropin secretion in polycystic ovary syndrome: influence of adiposity. J Clin Endocrinol Metab 1997;82:3728-33.

16) McCartney CR, Blank SK, Prendergast KA, Chhabra S, Eagleson CA, Helm KD, et al. Obesity and sex steroid changes across puberty: evidence for marked hyperandrogenemia in pre- and early pubertal obese girls. J Clin Endocrinol Metab 2007;92:430-6.

17) Bordini B, Littlejohn E, Rosenfield RL. LH dynamics in overweight girls with premature adrenarche and slowly progressive sexual precocity. Int J Pediatr Endocrinol 2010;2010:724696.

18) McCartney CR, Prendergast KA, Chhabra S, Eagleson CA, Yoo R, Chang RJ, et al. The association of obesity and hyperandrogenemia during the pubertal transition in girls: obesity as a potential factor in the genesis of postpubertal hyperandrogenism. J Clin Endocrinol Metab 2006;91:171422.

19) Lawson MA, Jain S, Sun S, Patel K, Malcolm PJ, Chang RJ. Evidence for insulin suppression of baseline luteinizing hormone in women with polycystic ovarian syndrome and normal women. J Clin Endocrinol Metab 2008;93:2089-96.

20) Tortoriello DV, McMinn J, Chua SC Dietary-induced obesity and hypothalamic infertility in female DBA/2J mice. Endocrinology 2004;145:1238-47.

21) Lee HS, Yu JE, Yi KH, Hwang JS. Clinical and biochemical factors associated with GnRH stimulation test in the idiopathic central precocious puberty and early puberty girls. J Korean Soc Pediatr Endocrinol 2008;13:41-9.

22) Nam HK, Rhie YJ, Son CS, Park SH, Lee KH. Factors to predict positive results of gonadotropin releasing hormone stimulation test in girls with suspected precocious puberty. J Korean Med Sci 2012;27:194-9.

23) Kim HJ, Kim YH, Chung SC. Growth status and body composition in children with central precocious puberty and early puberty. Ann Pediatr Endocrinol Metab 2012;17:169-74. 


\section{성조숙증 및 조기사춘기 여아에서 체질량지수가 성선자극호르몬 방출호르몬 자극에 의한 황체화호르몬 농도 증가에 미치는 영향}

\section{이성용}

보라매병원 소아청소년과

목적: 본 연구는 중추성 성조숙증 및 조기사춘기 여아에서 체질량지수가 $\mathrm{GnRH}$ 자극검사 시 $\mathrm{LH}$ 최고농도에 미치는 영향을 알아보고자 시행되었다.

방법: $\mathrm{GnRH}$ 자극검사상 사춘기 반응을 보인 7세에서 9 세 사이의 여아 113 명을 대상으로 의무기록을 후향적으로 검 토하였다. 진단시 역연령, 골연령, 신장, 체중, 체질량지수, $\mathrm{LH}$ 와 FSH의 기저 및 최고농도, 기저 에스트라디올 농도를 조사하였다.

결과: LH 최고농도는 체중 표준편차점수와 체질량지수 표준편차점수와 음의 상관관계를 보였고 FSH 기저 및 최고농 도와 양의 상관관계를 보였다. 다중회귀분석 결과 체질량지수 표준편차점수는 LH 최고농도에 영향을 미치는 의미 있 는 결정인자였다. $\mathrm{LH}$ 최고농도의 사분위수를 기준으로 4군으로 나누었을 때 $\mathrm{LH}$ 최고농도가 가장 높은 군의 체질량지 수는 LH 최고농도가 가장 낮은 군의 체질량지수 보다 의미 있게 낮았다.

결론 : 성조숙증 및 조기사춘기 여아에서 체질량지수가 높을수록 $\mathrm{GnRH}$ 자극검사 시 $\mathrm{LH}$ 최고농도는 감소한다. 따라 서 여아에서 성조숙증 진단시 체질량지수에 의한 영향을 고려하여야 할 것으로 보인다. 